\title{
Jacqueline Cerquiglini-Toulet, Christine de Pizan et le scandale: naissance de la femme écrivain
}

\section{Maria Colombo Timelli}

\section{(2) OpenEdition}

1 Journals

\section{Édition électronique}

URL : http://journals.openedition.org/studifrancesi/27262

DOI : $10.4000 /$ studifrancesi.27262

ISSN : 2421-5856

Éditeur

Rosenberg \& Sellier

\section{Édition imprimée}

Date de publication : 31 décembre 2006

Pagination : 581

ISSN : 0039-2944

\section{Référence électronique}

Maria Colombo Timelli, « Jacqueline Cerquiglini-Toulet, Christine de Pizan et le scandale: naissance de la femme écrivain », Studi Francesi [En ligne], 150 (L | III) | 2006, mis en ligne le 30 novembre 2015, consulté le 08 novembre 2020. URL : http://journals.openedition.org/studifrancesi/27262 ; DOI : https://doi.org/10.4000/studifrancesi.27262

Ce document a été généré automatiquement le 8 novembre 2020.

\section{(c) $(1) \ominus$}

Studi Francesi è distribuita con Licenza Creative Commons Attribuzione - Non commerciale - Non opere derivate 4.0 Internazionale. 


\title{
Jacqueline Cerquiglini-Toulet, Christine de Pizan et le scandale: naissance de la femme écrivain
}

\author{
Maria Colombo Timelli
}

\section{RÉFÉRENCE}

JACQUELINE CERQUIGLINI-TOULET, Christine de Pizan et le scandale: naissance de la femme écrivain, in «Toutes choses sont faictes cleres par escripture». Fonctions et figures d'auteurs du Moyen Âge à l'époque contemporaine. Études rassemblées par Virginie MINET-MAHY, Claude THIRY et Tania VAN HEMELRYCK, «Les Lettres Romanes», numéro hors série, 2004, pp. 45-56.

Cette contribution est bâtie sur le postulat de l'«irréductible étrangeté» de Christine de Pizan (p. 56), femme poète objet de scandale à plusieurs niveaux selon J. CerquigliniToulet: scandale sexuel d'abord, en tant que femme, «monstre par nature» selon le discours scientifique médiéval ; scandale intellectuel ensuite, en tant qu'écrivain ayant reçu ses dons de Dieu et de Nature; scandale politique enfin, en tant que femme capable de traiter de sujets philosophiques, de morale et de guerre. 